Володимир Шпортько,
Українська військово-медична академія, м. Київ ORSID 0000-0002-0805-4922

DOI: $10.33099 / 2617-1775 / 2019-02 / 157-165$

\title{
ФОРМУВАННЯ ПРОФЕСІЙНОЇ КУЛЬТУРИ МАЙБУТНІХ ВІЙСЬКОВИХ ЛІКАРІВ У ВИЩОМУ ВІЙСЬКОВО-МЕДИЧНОМУ ЗАКЛАДІ ЯК ПРОБЛЕМА ПРОФЕСІЙНОЇ ПЕДАГОГІКИ
}

У статті розглядається та обтрунтовується стан та перспективи розвитку формування професійної культури військових лікарів у педагогічній теорії $i$ практиці в умовах сучасної російсько-української війни, а також зроблено спробу пошуку нових підходів підготовки військових лікарів за умов переходу до стандартів НАТО.

Ключові слова: професійна культура; навчальний прочес; студенти медичних закладів; офіцери - лікарі; розвиток; ефективність.

Постановка проблеми. В умовах розвитку військової медицини набуває актуальність проблема формування професійної культури майбутніх військових лікарів для Збройних сил України. Під час сучасної російсько-української війни постала проблема щодо збільшення кількості військових лікарів, покращення їх практичних навичок щодо діяльності в бойових умовах, а також одночасно i підвищення їх професійної культури. Проблема підвищення професійної культури майбутніх військових лікарів набуває як теоретичної, так і практичної актуальності. Безумовно особливу роль у підготовці майбутніх офіцерів медиків відіграють науково-педагогічні працівники військово-медичних ВВНЗ.

Професійна культура лікаря - це частина загальнолюдської культури, яка проявляється у відповідному професійному середовищі, головним у якому $є$ лікарська діяльність із притаманними для неї традиціями, звичками, етичними нормами відповідною специфікою діяльності; це стан відношень професійної діяльності лікаря та суб'єктом - пацієнтом, станом його життям та здоров'я.

Професійна культура лікаря багатовимірна, охоплює його професійні знання, загальнокультурні та моральні цінності, відповідальність медичного працівника до виконання своїх обов'язків згідно зі клятвою Гіппократа. Велике значення має робота медичної установи, якість культури персоналу, система виховної роботи 3 усім колективом і особливо молодими лікарями та студентами медичних ВВН3, що забезпечує передачу лікарських традицій i культури.

Слід погодитись 3 думкою В. С. Чорного що «предметом головних зусиль керівників та науково-педагогічних працівників у галузі модернізації військової освіти повинні стати: мета, завдання, диверсифікація та індивідуалізація військової освіти; сучасні моделі інтеграції військової науки і військової освіти; інтеграція військової і цивільної освіти; соціально-психологічна адаптація військовиків екстремальних умовах; виховання в системі військової освіти, тощо» [1]. 
Актуальність проблеми формування професійної культури майбутніх військових лікарів зумовлена тим, що сучасна медицина у державі із виду надання медичної допомоги перетворилась в сферу надання послуг, дещо втратила орієнтацію на загальнолюдські цінності, які покладаються на лікарів. А в умовах російсько-української війни на сході України значна частина військовослужбовців і цивільного населення отримує поранення, зазнає психогенного впливу внаслідок перебування у районі операції об'єднаних сил що потребує професійного лікування та посттравматичної адаптації. В цих умовах проблема професійної культури лікаря набуває великого значення.

Аналіз досліджень і публікацій. 3 погляду на історію розвитку людства, питання професійної культури, медичної етики та деонтології висвітлювались положеннях «Законів Хаммурапі» (Закони Стародавнього Вавилону, 18 ст. до н.е.), «Клятва», «Закон Гіппократа» ( 5-4 вік до н.е.), «Канон лікарської науки», «Етика», Ібн-Сіни (Авіцени 10-11 ст. н. е.), «Щоденник старого лікаря», «Листи iз Гейдельберга» М. І. Пирогова. Вимоги до професійної культури лікарів знайшли відображення у «Женевській декларації» присязі лікаря (1948), «Міжнародному кодексі медичної етики» (1949), «Гельсінській декларації прав людини» (1964), «Міжнародній декларації у правах людини» (1983).

Важливими в контексті проблеми формування професійної культури лікарів є праці Е. В. Белоконева, Ю. В. Вороненка, О. І. Гури, О. П. Мінцера, В. В. Краснова, О.С. Кульбаха О. В. Парахіна, в яких розглянуто питання професійної культури лікарів, а також обгрунтована система підвищення кваліфікації викладачів вищої військово-медичної освіти (Я. Ф. Радиш, А. І. Романенко, В. В. Солярик, та ін.).

Особливості підготовки військових лікарів, підвищення їх професійної культури присвячені праці М. П. Бойчака, Л. А. Голика, В. О. Жаховського, Б. А. Клішевича, Я. Ф. Радиша, Ю. В. Рум'янцева та ін.

Мета статті. Проаналізувати наявні наукові джерела та з'ясувати як проблема формування професійної культури військових лікарів досліджена в нині у вищому військово-медичному закладі. Виявити які напрями підвищення професійної культури військових лікарів $є$ пріоритетними.

Методи дослідження. Для розв'язання завдань дослідження використано аналіз наукової літератури, порівняння, класифікація, узагальнення i систематизація матеріалу.

Виклад основного матеріалу. Професійна культура лікаря, про що стверджує військова педагогіка, висновки спеціальної методичної літератури, охоплює ставлення до виконання своїх професійних обов'язків, взаємовідносин у процесі лікарської та навчально-лікарської практики. Весь персонал військово-медичного закладу є учасником сфери відношень у ході професійної діяльності, до якої входять культура даної діяльності та особиста відповідальність за якість вирішення поставлених завдань. Крім того до рис професійної культури військових лікарів слід віднести такі якості як критичність до професійних помилок [2], милосердя, самовідданість та сумлінність, бездоганне виконання обов'язків лікаря, клятви Гіппократа [3]. 
Професійна культура військового лікаря - це набута ступінь професійних і моральних цінностей яка створена протягом тривалого часу поколіннями лікарів. Професіоналізм лікаря - це комплекс створених i визнаних у лікарському середовищі еталонів здійснення професіональної діяльності. Суть людяності у лікаря - це спокійна стійкість етичної перспективи, вольове та інтелектуальне подолання труднощів у їі практичному здійсненні [4].

У професіоналізмі лікаря слід виділити стійкі норми і цінності, які зумовлюють взаємодію із пацієнтами, які змушені довіряти лікарям, не маючи достатніх знань для оцінювання якості лікування, кваліфікації лікаря. Форми контролю за індивідуально-особистісними якостями лікаря є традиційними. Вони базуються на засвоєнні норм деонтології та медичної етики, і мають утримувати лікаря від свідомих порушень у лікувальній справі.

Сучасний розвиток професійної культури військового лікаря зумовлює розвиток форм внутрішнього професійного контролю. Це велика відповідальність начальників кафедр, відділень, провідних фахівців за військово-медичною спеціалізацією. На сучасному етапі розвитку військової медицини набуває достатнє поширення доцільність до командних принципів прийняття рішень у складних питаннях визначення діагнозу та лікування, оперативність у роботі.

Зважаючи на формування професійної культури військових лікарів важливе місце визначає вирішення таких стосунків як: лікар-хворий, лікарродичі хворого, лікар-лікар. Особливе місце належить турботі та увазі до хворого. Важливе значення має почуття такту, культура мови [5], вміння підбадьорити пацієнта. Особливо важливо вміти вислухати людину у співбесіді, продемонструвати зацікавленість змістом проблеми хворого, доступна мова у спілкуванні із пацієнтом.

Лише високоморальний військовий лікар може надавати якісну допомогу своїм пацієнтам, турбуватися про їх здоров'я, створювати сприятливі умови для ïx одужання, підвищення працездатності. Тому якісна робота 3 організації воєнно-педагогічного процесу на військових кафедрах вищих медичних закладів та Української військово-медичної академії створює умови підготовки висококультурних фахівців готових до роботи і діях у різних комунікативних ситуаціях. «Лише глибоке розуміння важливості і цінності людського життя, необхідності турботи про нього, потреба у збереженні здоров'я дасть молодому фахівцю змогу повною мірою самореалізуватись» [6].

Сучасний світ піднімає роль гуманізації всіх сторін діяльності медицини в наслідок чого духовні цінності мають велике значення. Питання розвитку професійної культури лікаря тісно взаємопов'язане 3 розвитком його мови. Мова $є$ цементуючою основою професійної культури. Зважаючи на це слід зазначити що в даному напрямку розвитку професіональної культури майбутнього військового лікаря $є$ значні прогалини. Мова йде не тільки суто про категорійний контент професійної мови лікаря а і ії українську складову, як базову державну. Значні недоліки існують із знанням іноземних мов, зокрема англійської, встановленої мови для ЄС та НАТО. 
Постає проблема ролі розвитку i удосконалення мови майбутніх військових лікарів як процесу їх спілкування і комунікації, особливо в умовах ведення проти нашої держави так званої «гібридної війни» [7] із усіма подальшими наслідками. Наказ Міністра оборони України від 25.04.2016 № 216 «Про вдосконалення підготовки офіцерських кадрів тактичного рівня та сержантського (старшинського складу) у вищих військових навчальних закладах та військових навчальних підрозділах вищих навчальних закладів» передбачає обов'язкове вивчення іноземної мови. Але практично рівень підготовки військових лікарів 3 професійної іноземної мови слабкий, військова і військово-медична термінологія, наприклад англійською мовою не засвоєна на належному рівні. До УВМА приходять громадяни які уже закінчили медичні навчальні заклади та пройшли навчання за програмою підготовки офіцерів медичної служби запасу і вони лише частково вивчали іноземну мову, що $\epsilon$ недоліком у їх підготовці. У УВМА слід ввести для навчання дисципліну «Іноземна мова» (військово-спеціальна мовна підготовка).

Важливою складовою формування професійної культури військових лікарів $\epsilon$ ефективність правового виховання яка не завжди у повному обсязі відповідає сучасним вимогам. У деяких закладах вищої медичної освіти ця робота не має системного характеру, планується і проводиться без урахування реального стану правопорядку, змін у соціально-політичній обстановці та їхнього впливу на соціально-психологічний клімат у колективах студентів та слухачів.

Таким чином нагальна проблема удосконалення правового виховання студентів-лікарів $\epsilon$ також елементом формування їх професійної культури, що у подальшому вплине на якість правовиховної роботи майбутніх керівників військово-медичних підрозділів.

Практичні питання ефективності правового виховання вимагають постійної уваги з боку керівного складу учбових закладів, якісного проведення занять 3 основ законодавства та права. Підвищення рівня правової свідомості [8], правової культури законослухняності, правомірної поведінки та соціальноправової активності особи, правового виховання є питаннями що ставляться сьогодні у державі у зв'язку із підвищенням соціального значення права у суспільстві.

Ефективність правового виховання майбутніх військових лікарів це передусім отриманий результат, який вимірюється співвідношенням досягнутого рівня правовиховної роботи та тією бажаною метою, яку ставили перед собою керівники, педагоги, вихователі та інші учасники правовиховної роботи і якої необхідно було досягти.

Формування правової переконаності студентів - це досить складний процес, що одночасно характеризується як ідеологічний, інтелектуальний i психологічний, на хід якого впливає низка позитивних та негативних чинників, зокрема економічних, організаційних, побутових, соціально-психологічних тощо. 
Значною мірою на підвищенні рівня професійної культури майбутніх військових лікарів позначається стан педагогічної компетентності науковопедагогічних працівників ВВМНЗ, які наразі здійснюють науково-педагогічну діяльність у системі вищої військово-медичної освіти [9]. Цей фактор стає важливим важелем їхньої успішної діяльності $з$ підвищення кваліфікації військових лікарів та підготовки їх до вирішення складних військовомедичних і науково-педагогічних завдань.

Розглядаючи питання професійної культури військових лікарів слід підкреслити що більшість аспектів що впливають на формування професійної культури лікаря відбуваються в системі їх професійної освіти. Освіта є основою розвитку особистості, суспільства, нації та держави, запорукою майбутнього України. Вона $є$ визначальним чинником політичної, соціально-економічної, культурної та наукової життєдіяльності суспільства. Освіта відтворює і нарощує його інтелектуальний, духовний та економічний потенціал [10].

Актуальні завдання вітчизняної військової освіти та науки не можливо розв'язати на підставі старих методологічних засад організації та здійснення навчально-наукового процесу в Збройних силах України. Серед головних завдань що сприятимуть процесу підвищення якості національної системи вищої освіти та виходу на світовий освітянський простір, за думкою В.В. Ягупова [11] слід зазначити такі: удосконалення системи підготовки військових фахівців у цивільних вищих навчальних закладах, інтегрованих навчальнонаукових комплексах, факультетах i навчальних центрах; підвищення ефективності військово-наукових розробок та досліджень, використання отриманих результатів на практиці. Провідна роль у цьому належить науковопедагогічним працівникам, які мають показувати особистий приклад дотримання етичних норм у педагогічній і науковій діяльності [12].

За поглядами військових фахівців Великобританії, з метою підвищення професійної культури військових лікарів окрім покращення систем контролю за діяльністю лікарів у військово-медичних установах та військово-медичних закладах достатня увага приділяється розвитку неформальної системи співробітництва військових лікарів. Це досягається проведенням робочих зустрічей, обідів, конференцій, виданням академічних журналів. Система допомагає створювати гарні робочі стосунки, формувати соціальні відносини у командах лікарів [13].

У системі підготовки військових лікарів країн НАТО напрацьований достатній досвід співробітництва вищих ведичних закладів та навчальних медичних закладів міністерств оборони країн альянсу. Міжнародна кооперація країн НАТО поглиблюється зважаючи на існуючі військові загрози та оптимізацію системи взаємодії у військових конфліктах. За думкою Т. Молнара та А. Місета [14] акцент кооперації країн НАТО в медичній сфері йде через систему підготовки військових медиків у курсовій мережі, за військовомедичними спеціальностями при медичних університетах країн. На курси залучають представників країн НАТО, на прикладі Угорщини, Німеччини та Великої Британії. Одночасно іде поглиблена кооперація цивільних та 
військових вищих військових закладів з метою оптимізації досвіду, розробки новітніх технологій та підвищення професіональної культури військових лікарів. Участь України у такій кооперації є перспективною і необхідною, що слід вирішувати через систему перспективного планування військового міжнародного співробітництва Міністерства оборони України шляхом включення у програму заходів міжнародного військового співробітництва для досягнення цілей партнерства з НАТО.

Висновки та перспективи подальших досліджень. Аналіз матеріалів наведених у статті засвідчив що сучасні дослідження приділяють велику увагу теоретичним i прикладним аспектам формування професійної культури медичних працівників. В той же час проблема формування професійної культури військових лікарів досліджено недостатньо і потребує подальшого вивчення $з$ метою удосконалення якісної системи підготовки у вищих медичних закладах та Українській військово-медичній академії.

Висновки та результати подальших досліджень щодо професійної культури військових лікарів, які готуються у вищих медичних закладах України допоможуть створити належні умови оптимізації навчального процесу, морально-психологічного забезпечення підготовки військових медиків.

Особливе місце у подальших дослідженнях належить питанням адаптації військово-медичної освіти до стандартів НАТО, набуття передового досвіду у професійній підготовці, освоєнні нових технологій та системи роботи як із військовими лікарями так і їх пацієнтами.

\section{ЛІТЕРАТУРА}

1. Чорний В.С. Розвиток військової освіти України на сучасному етапі: концептуальний вимір / В.С. Чорний // Збірник наукових праць «Військова освіта» Національного університету оборони України. - 2012. - № 1 (25). - С. 15-21

2. Пирогов М.И. Севастопольские письма и воспоминания. - М. Издательство АН CCCP, 1950.

3. Клятва Гіппократа // Медицина і право. /Електронний ресурс/. - Режим доступу htth: // www.med-pravo.ru/Ethics/VowYippocr.htm.

4. Э. Лютер, А. И. Смольняков. Личность больного и деонтологическая практика врача. Медицинская этика и деонтология. / под. Ред. Г. В. Морозова. Г.И. Царегородцева. М.Медицина, 1983. - С. 113-122.

5. Соколова В.В. Культура речи и культура общения. М. Просвещение. 1995 г.

6. Лаптева В. И. Проблемы духовно-нравственного воспитания студентов медицинского вуза / Лаптева В. И., Астапенко Е.Ф., Коваленко И.В., // Личность, семья и общество: вопросы педагогики и психологии: материалы XXXIX Международ. Науч.-практ. конф. (14 апреля 2014, Новосибирск). (Електронный ресурс). - htth://sibas.info.

7. Нікітюк О. В., Шпортько В.О. Значення вивчення іноземної мови при підготовці військово-медичних фахівців. Збірник тез доповідей Міжнародної науково-практичної конференції, 12-13 09.2019, Військова академія, м.Одеса. С. 367-368.

8. Когут Н. Актуальні питання становлення правосвідомості молоді / Неля Когут // Вісник Академії управління МВС України. Науковий журнал. - №4(16). - 2010. - С. 197-203.

9. Гончаренко I. Ф. Модель розвитку психолого-педагогічної компетентності науковопедагогічних працівників військово-медичної сфери у системі післядипломної освіти / I. Ф. Гончаренко // Збірник наукових праць Національної академії Державної прикордонної служби України. - Хмельницький : НАДПСУ, 2014. - № 4 (73). - С. 118-131. 
10. Нещадим М. І. Військова освіта України: історія, теорія, методологія, практика: могнографія / - К.: Видавничо-поліграфічний центр «Київський університет», 2003. - С. 852

11. Ягупов В.В. Військова освіта в Україні та її вплив на національну безпеку / В.В. Ягупов // Освіта як фактор національної безпеки. - Матеріали Всеукраїнської науковопрактичної конференції. - К.: Академія муніципального управління., 2003. - С. 124-132.

12. Ягупов Василь. Наукова етичність як провідний методологічний і життєвий принцип академіка Семена Гончаренка // Лицар педагогічної науки : науково-популярне видання до 90-річчя від народження академіка Семена Устимовича Гончаренка [колектив авторів] / За заг. ред. Л.Б. Лук'янової ; упоряд. : О.В. Аніщенко, А.М. Самко. - К. : ТОВ «ДКС-Центр», 2018. - С.125-136.

13. Мартин С.М., Брікнелл М.С. Культурний виклик лідера у військовій медицині. 2009. Альманах воєнної медицини. Оборонні медичні служби. https://www.gov.uk/government/groups/defence-medical-services

14. Молнар Т., Місета А., Рендекі С. Потенційна роль медичних шкіл університетів у військово-цивільному співробітництві. - Альманах: Міжнародний форум медичного корпусу, Угорщина - 2/ 2015.

\section{REFERENCES}

1. Chornyi V.S. Rozvitok vyiskovoi osvity Ukraini na suthasnomu etapi: kontseptualniy vimir / V. S. Chornyi // Zbirnik naukovih prats «Viyskova osvita» Natsionalnogo universitetu oboroni Ukraini - 2012. - № 1 (25). - C. 15-21

2. Pirogov M.I. Sevastopolskie pisma I vospominanija. - M. Izdatelstvo AN SSSR, 1950.

3. Kliatva Gippokrata // Meditsina I parvo // Eletktronniy resurs/. - Regim dostupa htth: // www.med-pravo.ru/Ethics/VowYippocr.htm.

4. E. Luter, A.I.Smolniakov/ Lithnost bolnogo i deontologitheskaja praktika vratha. Meditsinskaja etika I deontologija. / pod Red. / G.V.Tsaregorodtseva. M. - Meditsana, 1983. - C. 113-122.

5. Sokolova V.V. Kultura rethi I kultura obshenija. M. Prosveshenije. 1955.

6. Lapteva V.I. Problemi duhovnogo - nravsvennogo vospitanija studentov meditsinskogo vuza / Lapteva V.I., Astapenko E.F., Kovalenko I.V., // Lithnost, semja i obshestvo: voprosi pedagogiki I psihologii: materiali XXXIX Meshdunarodnoi nauthno - prakt. Konf. (14 apreljia 2014, Novosibirsk). (Elektroniy resurs). - htth://sibas.info.

7. Nikitiuk O.V., Shportko V.O. Znathenija vivthennia inozemnoji movi pri pidgotovtsi vijskovo-medithnih fahivtsiv. Zbirnik tez dopovidei Mishnarodnoi naukovo-praktihnoi konferentsii, 12-13 09. 2019, Vijskova akademija, m. Odesa. C. 367-368.

8. Kogut N. Aktualni pitannia stanovlenjia pravosvidomosti molodi / Nelia Kogut // Visnik Akademii upravlinnia MVS Ukraini. Naukovij gurnal. - №4(16). - 2010. - C. 197-203.

9. Gontharenko I.F. Model rozvitku psihologo-pedagogithnoi kompetentnosti naukovopedagogithnih pratsivnikiv vijskovo-medithnoi sferi u sistemi pisliadiplomnoi osviti / I.F. Gotharenko // Zbirnik naukovih prats Natsionalnoi akademii Dershavnoi prikordonnoi slugbi Ukraini. - Khmelnitskyi : NADPSU, 2014. - № 4 (73). - C. 118-131.

10. Neshadim M.I. Vijskova osvita Ukraini: istorija, teorija, metodologija, praktika: monografia / - K.: Vidavnithno-poligrafithniy thsentr «Kyivskyi universitet» 2003. - C. 852

11. Jagupov V.V. Vijskova osvita $v$ Ukraini ta ii vpliv na natsionalnu bezpeku / V.V. Jagupov // Osvita jak factor natsionalnoi bezpeki. - Materiali Vseukrainskoi naukovo-praktihnoi konferentsii. - K.: Akademija munitsepalnogo upravlinnia., 2003. - C. 124-132.

12. Jagupov Vasil. Naukova etithnist jak provodnuy metodologithnij i gitteviy printsip akademika Semena Gontharenka // Litsar pedagogithnoi nauki: naukovo-populiarne vidannija do 90-ritha vid narodgennija akademika Semena Ustimovitha Gontharenka [kolektiv avtoriv] / Za red. L.B. Lukjanovoi, uporjadn.: O.V. Onishenko, A.M. Samko/ - K.: TOV «DKS - tsentr», 2018. C.125-136. 
13. Martin S.M., Briknell M.S. Kulturniy viklik lidera u viuskovii meditsini. 2009. Almanah voennoi meditsini. Oboronni medithni slugbi. https://www.gov.uk/government/groups/defencemedical-services

14. Molnar T., Miseta A., Rendeki S. Potensijna rol medithnih shkil universitetiv u viyskovo-tsivilnomu spivrobitnitstvi. Almanah: Mishnarodniy forum medithnogo korpusu, Ugorshina - 2/ 2015.

\section{РЕЗЮМЕ}

\section{Владимир Шпортько,}

Украинская военно-медицинская академия, г. Киев

\section{Формирование профессиональной культуры будущих военных врачей в высшем военно-медицинском заведении как проблема профессиональной педагогики}

Целью статьи является исследование вопроса формирования профессиональной культуры будущих военных врачей в высшем военно-медицинском заведении. Для этого применялись общенаучные методы исследования. В период российско-украинского военного конфликта при большом росте раненых и пострадавших роль профессиональной культуры врача имеет приоритетное значение. Поиск новых форм и методов работы в направлении улучшения профессиональной культуры военного врача, его обучения в высшем военномедицинском заведении имеет практическое прикладное значение.

С учетом евроатлантических устремлений Украины, ее вооруженных сил и военномедицинского обеспечения актуальным есть потребность адаптации до стандартов НАТО в вопросах предоставления медицинских услуг военнослужащим, системы их лечения и реабилитации. Это выдвигает потребность дальнейшего исследования системы подготовки будущих военных врачей и разработку необходимых рекомендаций повышения их профессиональной культуры.

Ключевые слова: профессиональная культура; учебный прочесс; студенты медииинских заведений; офицеры - врачи; развитие; эффективность.

\section{SUMMARY}

Volodymyr Shportko, Ukrainian Military Medical Academy, c. Kyiv

\section{Formation of professional culture of future military doctors in higher military medical institution as a problem of professional pedagogy}

Introduction. Doctors' professional culture is multi-dimensional and covers professional, cultural and moral values, acquires both theoretical and practical relevance.

Purpose. The problem of forming of future military doctors` professional culture gains more relevance in context of military medicine development. The article analyzed available scientific sources and information, clarifies how the issues of doctors 'professional culture have been researched in higher medical institutions and what directions of development of doctors ' professional culture have got priorities.

Research methods. The analysis of scientific literature, comparison, classification, generalization and systematization of the material were used in solving the research tasks.

Results. The article reveals the relation between the problem of modernization of society and the need to improve the professional culture of military doctors. The maim role in the process of enhancing the professional culture of students of higher medical institutions and students of Ukrainian military academy (UMMA) is the responsibility of the scientific and pedagogical staff of universities.

The author emphasis that acquired level of professional culture of future military doctors has significant shortfalls that are inherent in modern Ukrainian society. There is an attempt to 
emphasize a necessary of qualitive changes in the medical student's educational process, especially in foreign language studying, quality of mastering the law and international law.

Scientific novelty and practical significance of research results. For the first time the organization and pedagogical conditions for forming the professional culture of future military doctors in higher military medical institution was theoretically substantiated as a pedagogical problem.

An attempt was made to show a set of interrelated multidimensional elements of professional culture of military doctors.

The system of a new views on improving the professional culture of students of higher medical institutions and UMMA'S students was improved. Among the most urgent requirements for the professional culture of future doctors, the attention is focused on the effectiveness of studying of legislation and foreign language training. Author emphasizes the need of study and implementation of EU and NATO experience in military doctors training, which will help to achieve the necessary partnership goals.

Conclusions and prospects for future research. Modern research pays much attention to theoretical and practical aspects of formation of the professional culture of medical professionals. At the same time, the formation of the professional culture of military doctors in the system of training in higher medical institutions has not been sufficiently studied.

The conclusions and results of further on the professional culture of military doctors trained at universities in Ukraine will help to create some proper conditions for optimization of education progress, moral and psychological support to the military doctors training.

Key words: professional culture; studying proccess; medical students; officers - doctors; development; efficiency. 